\title{
ETHYLENE, ENZYMATIC AND RESPIRATORY PATTERN EVOLUTION IN LOQUAT (Eriobotrya japonica (Thunb.) Lindl.) CV. GOLDEN NUGGET IN THE LAST FOUR SEQUENTIAL STAGES OF MATURATION
}

\author{
Pedro L. Undurraga M. ${ }^{*}$, José A. Olaeta C. ${ }^{1}$, and Cristian Cancino ${ }^{1}$
}

There is some controversy regarding the respiratory pattern of loquat (Eriobotrya japonica [Thunb.] Lindl.). Thus in order to provide information on this aspect of loquat, fruit of 50-70 g, from cv. Golden Nugget were harvested in four stages of maturity: green (BBCH 709), color break (BBCH 801), yellow (BBCH 807), and orange (BBCH 809). The parameters evaluated in each stage were: soluble solids, titratable acidity, respiration, ethylene generation, and activity of the enzymes pectin methyl esterase (PME), peroxidase, polyphenoloxidase (PPO), polygalacturonase (PG), and cellulose, and the soluble solids:acidity ratio was calculated. The results show that ethylene concentration increased at the time of color break, which was not the case for the change in the respiratory rate. The activity of the peroxidase enzyme increased from the green stage to color break, while the enzymes PME, cellulase, and PG showed a constant reduction from the green to the orange stage, and PPO showed no change over the four stages studied. With regards to quality, from color break onwards soluble solids increased to $11.8{ }^{\circ}$ Brix and titratable acidity dropped from 0.67 to $0.28 \mathrm{~g} \mathrm{~L}^{-1}$ malic acid. Based on these results, the conclusion is that towards the end of its development loquat cv. Golden Nugget evidence enzymatic and ethylene behavior similar to that of climacteric fruits.

Key words: Color skin, peroxidase, $\mathrm{CO}_{2}$, fruit quality, polygalacturonase.

$\mathrm{T}$ he loquat (Eriobotrya japonica [Thunb.] Lindl.) is a subtropical evergreen fruit tree of the family Rosaceae, subfamily Pomoideae native to southeast China (Gariglio et al., 2002). It was introduced to Europe in the $18^{\text {th }}$ century and has been cultivated in countries such as Italy, Spain, Turkey, and others (Llácer et al., 1995).

Cultivation in Chile is mainly restricted to the cv. Golden Nugget, which produces oval fruits that are yellow-orange in peel and flesh, with a mean weight of $54 \mathrm{~g}$ and a mean diameter of $45 \mathrm{~mm}$ (Martínez-Calvo et $a l ., 2000)$. The degree of perishability of any fruit and its postharvest management are strongly linked. In general perishability is proportional to respiratory behavior, meaning that fruit can be classified in terms of this aspect and ethylene production, as either climacteric or nonclimacteric (Kader, 1985).

The loquat fruit is traditionally associated with nonclimacteric fruits, as it shows no signs of increased respiration or ethylene production after harvesting or in the period immediately before (Blumenfeld, 1980; Razeto, 1988; Zhang et al., 1990; Zheng et al., 1993; Chachin and

${ }^{1}$ Pontificia Universidad Católica de Valparaíso, Facultad de Agronomía, Casilla 4-D Quillota, Chile.

*Corresponding author (pundurra@ucv.cl).

Received: 16 March 2011.

Accepted: 13 July 2011.
Hamauzu, 1997; Ding et al., 1998a; Kader, 2002; Tobar, 2004; Wang et al., 2010). However, some authors have found a rise in respiration and in ethylene generation during the last period of fruit growth and development, thus assigning climacteric behavior and at the same time causing controversy with regards to its true respiratory pattern (Hirai, 1980; 1982; Hamauzu et al., 1997; Amorós et al., 2003; Cortés 2003).

Christoffersen et al. (1982) studying avocado (Persea americana Mill.) and Speirs et al. (1984) studying tomato (Lycopersicum esculentum Mill.) have stated that protein analysis during maturation of climacteric fruits shows that enzyme formation occurs in the pre-climacteric stage in order to regulate the transformation of several reserve compounds, causing fruit maturation. This aspect has not been greatly studied in the case of loquat, so that finding enzymatic formation and activation patterns in the fruit would support the theory that the loquat has a climacteric respiratory pattern. Alia-Tejacal et al. (2002) stated that one of the most relevant aspects of a climacteric fruit is increased synthesis of soluble proteins and increased activity of catalase, peroxidase, and polyphenoloxidase.

This research aims to evaluate the evolution of respiration and ethylene production, and the evolution of the activity of some enzymes related to the maturation and quality of loquat (E. japonica) cv. Golden Nugget, in the last four stages of fruit development, with the final 
objective of contributing to knowledge on its climacteric or non-climacteric status.

\section{MATERIALS AND METHODS}

The study was conducted at the La Palma Experimental Station ( $32^{\circ} 50^{\prime} \mathrm{S}, 71^{\circ} 13^{\prime} \mathrm{W}$ ) of the Faculty of Agriculture of the Pontificia Universidad Católica de Valparaíso, Chile. Some 304 loquat fruit 'Golden Nugget', between 50 and $70 \mathrm{~g}$ in weight, were separated into 76 fruit per each maturity stage. Maturity stages were determined according to skin color (Martínez-Calvo et al., 1999) as: green (BBCH 709), color break (BBCH 801), yellow (BBCH 807), and orange (BBCH 809) (Figure 1).

The following assessments were made for each stage of maturity: soluble solids (thermocompensated refractometer Atago, 0-32 ${ }^{\circ}$ Brix); titratable acidity (AOAC, 1984) expressed in g malic acid $100 \mathrm{~mL}^{-1}$ juice; soluble solids:acidity ratio; $\mathrm{pH}$ ( $\mathrm{pH}$-meter Schott-Geräte, measured in $20 \mathrm{~mL}$ of filtered juice); respiration (Dansensor gas analyzer model 9900, expressed in $\mathrm{mg} \mathrm{CO}_{2} \mathrm{~kg}^{-1} \mathrm{~h}^{-1}$ ); ethylene (Shimadzu GC 8 A gas chromatograph, with aluminum column and flame ionization detector [FID], results expressed in $\mu \mathrm{L} \mathrm{C}_{2} \mathrm{H}_{4} \mathrm{~kg}^{-1} \mathrm{~h}^{-1}$ ). The activity of the peroxidase and polyphenoloxidase (PPO) enzymes was determined using the Bradford method (Bradford, 1976) and expressed in units of activity per mg total protein. The activity of polygalacturonase was determined by the capacity of galacturonic acid release by the action of the enzyme in reducing dinitrosalicylic acid (DNS), and its absorption was determined at $540 \mathrm{~nm}$. Enzyme activity was expressed in $\mu$ moles min $^{-1}$ galacturonic acid released $\mu \mathrm{g}^{-1}$ protein (Menéndez et al., 2006).

In order to determine the activity of the pectin methylesterase (PME) enzyme, groups of released carboxyls were titrated in a citrus pectin solution (substrate) at $1 \%$ in $0.1 \mathrm{M} \mathrm{NaCl}$, as the enzyme extract was added. Enzyme activity was expressed in milliequivalents of hydrolyzed ester $\mathrm{mL}^{-1}$ extract $\mathrm{min}^{-1}$ reaction (Rouse and Atkins, 1952).
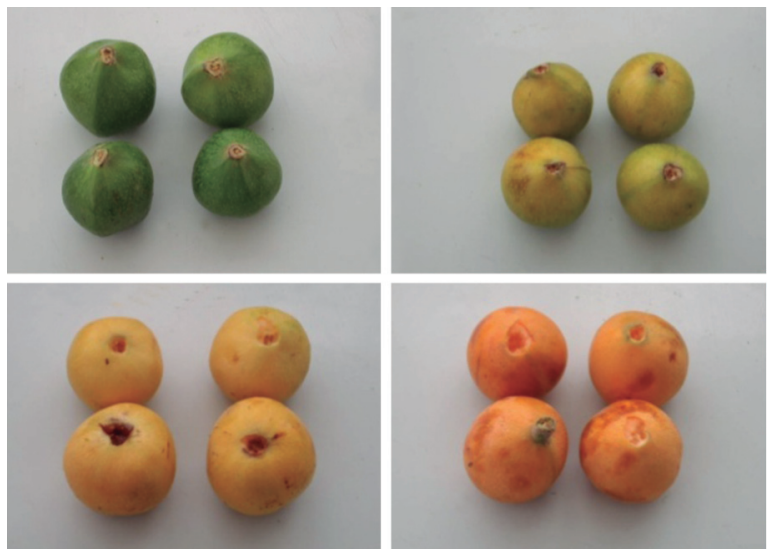

Figure 1. Maturity stages in loquat cv. Golden Nugget.
In the case of cellulase, the procedure began with incubation of the enzyme for $2 \mathrm{~h}$ at $37{ }^{\circ} \mathrm{C}$ under constant shaking. The sample was then dried and placed in an ice bath, allowing it to settle; it was then centrifuged and returned to storage. Later, $3 \mathrm{~mL}$ of glucose reactive was added and incubated. Absorption was measured at $340 \mathrm{~nm}$ in a Shimadzu spectrophotometer. Finally, 0.1 $\mathrm{mL}$ of sample supernatant was added and the increase in absorption at $340 \mathrm{~nm}$ was recorded for 3 to $5 \mathrm{~min}$. The cellulase activity was expressed as units of activity $\mathrm{mg}^{-1}$ total protein.

Five fruit were used for the measurement of soluble solids, titratable acidity, $\mathrm{pH}$, and the soluble solid:acidity ratio, ten fruit for the enzymatic analysis and four to evaluate respiratory activity and ethylene concentration, so that a total of 19 fruit were used per replicate to perform the measurements

A completely randomized design was used. Each loquat fruit was considered an experimental unit and for each treatment (each color-based maturity stage), four repetitions were carried out with 19 fruit each. The studied variables were analyzed with a one-way ANOVA. In the case that the maturity stages showed significant differences $(P \leq 0.05)$, mean separation was then performed using Tukey's test $(\alpha=0.05)$.

\section{RESULTS AND DISCUSSION}

\section{Quality parameters}

All the quality parameters evaluated over time were influenced by the stage of maturity. The maturity stages of color break (BBCH 805) and yellow (BBCH 807) present similar characteristics in terms of fruit quality (Table1), which may be because color development is primarily initiated by chlorophyll degradation, which in turn leads to an increase in the luminosity of the fruit without increasing color intensity (Amorós et al., 2003) or sugar and acid content. Only the subsequent formation of $\beta$-carotene and cryptoxanthin gives the fruit its final orange color (BBCH 809) (Hamauzu et al., 1997).

The marked increase in soluble solids from the green to orange stages is mainly due to an increase in sugar content, which begins simultaneously with the start of the rapid growth stage in the spring period and when the fruit has reached $70-80 \%$ of its final weight (Undurraga et

Table 1. Effect of the stage of maturity of loquat cv. Golden Nugget on soluble solids, acidity, soluble solids/acidity, and pH.

\begin{tabular}{lcccc}
\hline Maturity stage & $\begin{array}{c}\text { Soluble } \\
\text { solids }\end{array}$ & Acidity & $\begin{array}{c}\text { Soluble } \\
\text { solids/acidity }\end{array}$ & $\mathrm{pH}$ \\
\hline & ${ }^{\circ}$ Brix & $\mathrm{g} 100 \mathrm{~mL}^{-1}$ & & \\
Green & $4.86 \mathrm{a}$ & $0.67 \mathrm{a}$ & $7.44 \mathrm{a}$ & $2.81 \mathrm{a}$ \\
Color break & $7.27 \mathrm{~b}$ & $1.00 \mathrm{~b}$ & $7.49 \mathrm{a}$ & $2.93 \mathrm{a}$ \\
Yellow & $8.31 \mathrm{~b}$ & $0.95 \mathrm{ab}$ & $8.89 \mathrm{a}$ & $2.99 \mathrm{a}$ \\
Orange & $11.80 \mathrm{c}$ & $0.28 \mathrm{c}$ & $49.08 \mathrm{~b}$ & $3.51 \mathrm{~b}$ \\
\hline
\end{tabular}

Distinct letters in the same row indicate significant differences according to Tukey's test $(\mathrm{p} \leq 0.05)$. 
al., 2006). This result is in agreement with Gariglio et al. (2002), who reported that fructose represents 15 to $33 \%$ of the total sugar in the initial stages of fruit growth, and during color change it increases three times. Similarly, Amorós et al. (2003) found that in the color break stage of cv. Golden Nugget, sucrose increases sharply, before the initiation of the increase in glucose and fructose. Ding et al. (1998a) concluded that the most common soluble sugars and sugar alcohols found in loquats are fructose, sucrose, glucose, and sorbitol, and that sucrose accumulates before final maturity; which would mean a high increase in fructose and glucose in the first postharvest stages of the fruit. Kader (2002) states that consumers prefer fruit with sugar levels above $10 \%$, which was only achieved in our trial with the orange-colored fruit.

With respect to acidity, Guadarrama (2001) states that titratable acidity in most fruit trees tends to increase until a maximum is reached at physiological maturity, then falls during maturation, since organic acids are used as a substrate for respiration. This statement fully agrees with the results obtained in our research, in which we found an increase in acidity values in fruits with color break and a subsequent fall in orange fruits.

The main acid present in loquat is malic acid, which increases until immediately before color break and is responsible for $90 \%$ of total acidity, along with the presence of other organic acids, such as succinic, ascorbic, and fumaric, which also decrease with maturation. Another important acid is citric, which remains constant throughout fruit development (Uchino et al., 1994; Hamauzu et al., 1997; Ding et al., 1998a; Lin et al., 1999; Amorós et al., 2003).

The sugar-acid ratio changes and makes the fruit more palatable when it attains the orange color, as the ratio is above 20:1. The orange fruit had significantly higher $\mathrm{pH}$, which reflects a lower acidity that was not observed in earlier maturity stages, probably due to the buffer effect of the organic acids present in the fruit.

\section{Ethylene and respiratory activity}

There was a significant effect of the fruit maturity stages on the respiratory rate and ethylene generation (Table 2). The values obtained for respiration decreased significantly until the orange maturity stage in our trials, which agrees with the respiratory pattern of non-climacteric fruit where the respiratory rate normally shows a constant decline.

Table 2. Effect of the stage of maturity on respiratory rate and ethylene generation in fruit of loquat cv. Golden Nugget.

\begin{tabular}{lcc}
\hline Maturity stage & Respiration & Ethylene \\
\hline & $\mathrm{mg} \mathrm{CO}_{2} \mathrm{~kg}^{-1} \mathrm{~h}^{-1}$ & $\mu \mathrm{L} \mathrm{k}^{-1} \mathrm{~h}^{-1}$ \\
Green & $268.89 \mathrm{a}$ & $9.78 \mathrm{a}$ \\
Color break & $287.44 \mathrm{a}$ & $15.22 \mathrm{~b}$ \\
Yellow & $257.91 \mathrm{a}$ & $12.26 \mathrm{ab}$ \\
Orange & $74.62 \mathrm{~b}$ & $2.79 \mathrm{c}$
\end{tabular}

Distinct letters in the same row indicate significant differences according to Tukey's test $(\mathrm{p} \leq 0.05)$.
These results are contrary to those of Hirai $(1980 ; 1982)$; Hamauzu et al. (1997); Amorós et al. (2003), who found a significant, though slight, increase in the respiratory rate at color break. The situation with ethylene is quite different, as here a significant increase in concentration was observed as the fruit changed color from green to color break, which continues until yellow, before finally falling. This situation is representative of climacteric fruit. Chachin et al. (1990) observed similar behavior in loquats harvested in early stages, where the fruit had a small increase in $\mathrm{CO}_{2}$ and ethylene production, leading to the conclusion that this species presents a climacteric pattern.

Hirai (1980; 1982) and Amorós et al. (2003) concluded that the increase in ethylene in loquat is caused by the initiation of maturation, shown by the rise in respiration and color change, comparing it to the maturation of fruits such as apples and pears. This is very important when evaluating the respiratory pattern of the species, since the increase observed in ethylene production is characteristic of climacteric fruits and could be an indication that the climacteric stage occurs in this tree when the fruit begins to break down chlorophyll and synthesize carotenoids (Berger, 1988).

\section{Enzyme activity}

Analysis of enzyme activity shows that only the activity of polyphenoloxidase (PPO) registered no changes across the different stages of maturity. Peroxidase activity increased, while the activity of all the other enzymes analyzed decreased from the green to orange stages (Table 3).

Peroxidase activity increased significantly from green fruits to those in color break, remaining constant until the yellow stage, when it again dropped drastically. This is in line with the observations of Rao and Chundawat (1989) and Alia-Tejacal et al. (2002), who, working with Manilkara zapota (L.) P. Royen and Pouteria sapota (Jacq.) H.E. Moore \& Stearn respectively, found an increase in peroxidase activity, and attributed this to an increase in respiration, since the enzyme uses hydrogen peroxide as a substrate. This behavior has also been observed in different climacteric fruit, such as Pyrus communis and Lycopersicon esculentum (Frenkel, 1972), Mangifera indica L. (Mitra and Baldwin, 1997).

Table 3. Effect of the state of maturity on activity of: peroxidase, poliphenoloxidase (PPO), cellulase, pectin methylesterase (PME), and polygalacturonase in fruit of loquat cv. Golden Nugget.

\begin{tabular}{lccccc}
\hline Maturity stage & Peroxidase & PPO & Cellulase & PME & Polygalacturonase \\
\hline & \multicolumn{8}{c}{} & & $\mu \mathrm{g}$ galacturonic acid \\
& \multicolumn{6}{c}{ Units of activity/mg total protein } & $\mu \mathrm{g}^{-1}$ total protein \\
Green & $359 \mathrm{a}$ & $352 \mathrm{a}$ & $6443 \mathrm{a}$ & $15904 \mathrm{a}$ & $207 \mathrm{a}$ \\
Color break & $5241 \mathrm{~b}$ & $151 \mathrm{a}$ & $1215 \mathrm{ab}$ & $1669 \mathrm{~b}$ & $19 \mathrm{~b}$ \\
Yellow & $4268 \mathrm{~b}$ & $418 \mathrm{a}$ & $757 \mathrm{~b}$ & $1563 \mathrm{~b}$ & $24 \mathrm{~b}$ \\
Orange & $292 \mathrm{a}$ & $198 \mathrm{a}$ & $652 \mathrm{~b}$ & $879 \mathrm{~b}$ & $39 \mathrm{~b}$
\end{tabular}

Distinct letters in the same row indicate significant differences according to Tukey's test $(\mathrm{p} \leq 0.05)$. 
The increase found in the peroxidase activity in this assay, leaves a doubt about the results of respiration, since this enzyme is related to increases in the respiratory rate. Pérez-Tello et al. (1999) studied P. sapota, stored at $20{ }^{\circ} \mathrm{C}$, observing that peroxidase activity increased during maturation. This induction of maturation and initiation of senescence is probably due to the presence of free, possibly reactive, phenolic compounds, since the increase in peroxidase activity is linked, as stated, to the increase in respiration during the climacteric stage (Alia-Tejacal et al., 2002). After color break, peroxidase activity drastically decreased, which agrees fully with the decrease observed in the respiration rate in the orange fruits. Brady (1987) and Lelievre et al. (1997) stated that in climacteric fruit the rise in respiratory rate at the initiation of maturation is a response to an increase in ethylene, adding that in association with the increase in respiration, there is an increase in protein synthesis, which may be generated by a strong increase in messenger RNA. Bennett and Christoffersen (1986) indicated that in avocado (a climacteric fruit) there is clear evidence of a qualitative change in protein synthesis during maturation.

We found no significant effect of the stage of maturity on the activity of PPO. This is contrary to results reported by other authors, who state that the activity of this enzyme tends to decrease during the development and maturation of the fruit (Ding et al., 1998b; Casado Vela et al., 2002). Also, Cortés (2003) studied loquat fruit cv. Golden Nugget, observing that PPO activity decreased from color break onwards.

We found a significant effect of the stage of maturity on the activity of polygalacturonase (PG) in loquat fruit cv. Golden Nugget, which decreased at color break and remained constant afterwards. This behavior would indicate that the processes that lead to fruit softening begin at color break, the moment of the onset of structural pectic substance degradation, triggering the loss of firmness. Fruit softening during maturation is due to a large extent to alterations in the polysaccharides represented largely by polygalacturonide acids (Guadarrama, 2001), which are closely linked to PG activity.

From the analysis of PME, it can be observed that the activity of this enzyme is very high in green fruits, but progressively decreases as the fruit develops. This behavior is because PME activity, as with that of PG, is related to softening. In fact, in order for PG to be able to act upon the polygalacturonic acid, it must have a certain degree of demethylation, which is attributed to prior activity of PME (Guadarrama, 2001). This allows us to conclude that the degradation of the cell wall in loquat fruits, which leads to softening, occurs with the color break of the fruit and depends on the joint action of PG and PME.

Cellulase also shows a fall in activity at color break. Similar results were obtained by Abeles and Biles (1991) when studying the evolution of cellulase activity in apples.
This behavior is because the enzyme, as with PG and PME, participates in the degradation of cell walls during fruit maturation, showing the same behavior pattern as the aforementioned enzymes, by decreasing activity in fruits in the color break stage and then showing a progressive decline (Bennett and Christoffersen, 1986; Zanotti et al., 2009). This fact leads to the conclusion that the softening process of the loquat fruit cv. Golden Nugget is not the exclusive responsibility of one enzyme in particular, but rather of the joint participation of different hydrolytic enzymes in the cell wall, which occurs largely at the moment the chlorophyll breaks down and carotenoid synthesis begins, which corresponds to stage BBCH 801 .

\section{CONCLUSIONS}

The results of this study indicate that during the development of the loquat fruit cv. Golden Nugget, the stages of maturity, color break (BBCH 801) and yellow (BBCH 807) correspond to the same level of maturity in terms of fruit quality, respiration level, ethylene generation, and enzymatic activity. The quality characteristics increase from color break up to orange, with an increase in soluble solids and a fall in titratable acidity. With regard to the activity of the enzymes peroxidase, pectin methylesterase and cellulase, and ethylene generation, in the four latter stages of maturity, loquat fruit show similar behavior to that of climacteric fruits, while respiration is more similar to that of non-climacteric fruit.

Evolución del patrón respiratorio, enzimático y de etileno del níspero japonés (Eriobotrya japonica (Thunb.) Lindl.) cv. Golden Nugget en los últimos cuatro estadios secuenciales de madurez. Existe controversia sobre el patrón respiratorio del níspero (Eriobotrya japonica [Thunb.] Lindl.). Con el fin de aportar información sobre este aspecto, frutos del cv. Golden Nugget entre 50-70 g, fueron cosechados en cuatro estadios de madurez; verde (BBCH 709), quiebre de color (BBCH 801), amarillo (BBCH 807), y anaranjado (BBCH 809). Los parámetros evaluados en cada estadio fueron: sólidos solubles, acidez titulable, relación sólidos solubles acidez, respiración, generación de etileno y la actividad de las enzimas pectin metil esterasa (PME), peroxidasa, polifenoloxidasa (PPO), poligalacturonasa (PG), y celulasa. Los resultados muestran que el etileno incrementó su concentración al momento de quiebre de color, lo cual no fue equivalente en el cambio de la tasa respiratoria. La actividad de la enzima peroxidasa se incrementó desde el color verde al quiebre de color, mientras que las enzimas PME, celulasa, y PG mostraron una reducción constante desde el color verde hasta el color anaranjado y la PPO no se vió alterada en los cuatro estadios estudiados. Respecto a la calidad, a partir del quiebre de color se incrementaron los sólidos solubles hasta $11,8^{\circ}$ Brix y se redujo la acidez titulable desde 0,67 a 
0,28 $\mathrm{g} \mathrm{L}^{-1}$ de acido málico. Basado en estos resultados, se concluye que hacia el término de su desarrollo el fruto de níspero cv. Golden Nugget presenta un comportamiento enzimático y del etileno similar al que muestran frutos de tipo climatérico.

Palabras clave: color de piel, peroxidasa, $\mathrm{CO}_{2}$, calidad de fruta, poligalacturonasa.

\section{LITERATURE CITED}

Abeles, F., and C. Biles. 1991. Cellulase activity in developing apple fruits. Scientia Horticulturae 47:77-87.

Alia-Tejacal, I., M.T. Colinas-León, M.T. Martínez-Damián, y M.R. Soto-Hernández. 2002. Factores fisiológicos, bioquímicos y de calidad en frutos de zapote mamey (Pouteria sapota Jacq. H.E. Moore \& Stearn) durante poscosecha. Revista Chapingo Serie Horticultura 8:263-281.

AOAC. 1984. Official methods of analysis. $13^{\text {rd }}$ ed. Association of Official Analytical Chemists (AOAC), Washington DC., USA.

Amorós, A., P. Zapata, M.T. Pretel, M.A. Botella, and M. Serrano. 2003. Physico-chemical and physiological changes during fruit development and ripening of five loquat (Eriobotrya japonica Lindl.) cultivars. Food Science and Technology International 9:43-51.

Bennett, A.B., and R.E. Christoffersen. 1986. Synthesis and processing of cellulase from ripening avocado fruit. Plant Physiology 81:830-835.

Berger, H. 1988. Frutales no tradicionales. 180 p. Universidad de Chile, Santiago, Chile.

Blumenfeld, A. 1980. Fruit growth of loquat. Journal of the American Society for Horticultural Science 105:747-750.

Bradford, M. 1976. A rapid and sensitive method for quantitation of microgram quantities of protein utilizing the principle of proteindye-binding. Analytical Biochemistry 72:248-254.

Brady, C.J. 1987. Fruit ripening. Annual Review of Plant Physiology 38:155-178.

Casado Vela, J., S. Sellés Marchart, I. Gómez Lucas, and R.I. Bru Martínez. 2002. Evolution of phenolics and polyphenoloxidase isoenzymes in relation to physical-chemical parameters during loquat (Eriobotrya japonica cv. Algerie) fruit development and ripening. p. 161-164. In Llácer, G., and M.L. Badenes (eds.) Proceeding of I International Symposium on Loquat, Valencia, Spain. 11-13 April. Options Méditerranéennes: Série A. Séminaires Méditerranéens 58. 195 p.

Cortés, S. 2003. Efecto de la altitud de plantación en ladera de cerro, sobre la evolución de algunas características físico-químicas y bioquímicas del fruto de níspero (Eriobotrya japonica Lindl.). 86 p. Tesis Ingeniero Agrónomo. Pontificia Universidad Católica de Valparaíso, Facultad de Agronomía, Quillota, Chile.

Chachin, K., and Y. Hamauzu. 1997. Loquat. p. 397-404. In Mitra, S. (ed.) Postharvest physiology and storage of tropical and subtropical fruits. CAB International, Wallinford, UK.

Chachin, K., Y. Hamauzu, H. Kurooka, and T. Iwata. 1990. Physiological changes of loquat fruit after harvest. In Proceedings of XXIII International Horticultural Congress, Firenze, Italy.

Christoffersen, R.E., E. Warm, and G.G. Laties. 1982. Gene expression during fruit ripening in avocado. Planta 155:52-57.

Ding, C.K., K. Chachin, Y. Hamauzu, Y. Ueda, and Y. Imahori. 1998a. Effects of storage temperature on physiology and quality of loquat fruit. Journal of Postharvest Biology and Technology 14:309-315.

Ding, C., K. Chachin, Y. Ueda, and R. Mochioka. 1998b. Changes in polyphenol concentrations and polyphenol oxidase activity of loquat (Eriobotrya japonica Lindl.) fruits in relation to browning. Journal of the Japanese Society for Horticultural Science 67:360366.
Frenkel, C. 1972. Involvement of peroxidase and indole-3-acetic acid oxidase isozymes from pear, tomato, and blueberry fruit in ripening. Plant Physiology 49:757-763.

Gariglio, N., A. Castillo, M. Juan, V. Almela, y M. Agustí. 2002. El níspero japonés. Técnicas para mejorar la calidad del fruto. $61 \mathrm{p}$. Universitat Valenciana, Valencia, España.

Guadarrama, A. 2001. Fisiología postcosecha de frutos. 139 p Ediciones Universidad Central de Venezuela, Maracay, Venezuela

Hamauzu, Y., C. Chachin, K. Ding, and H. Kurooka. 1997. Differences in surface color, flesh firmness, physiological activity, and some components of loquat fruits picked at various stages of maturity. Journal of the Japanese Society for Horticulture Science 65:859-865.

Hirai, M. 1980. Sugar accumulation and development of loquat fruit. Journal of the Japanese Society for Horticultural Science 49:347353 .

Hirai, M. 1982. Accelerated sugar accumulation and ripening of loquat fruit exogenously applied ethylene. Journal of the Japanese Society for Horticultural Science 51:159-164.

Kader, A. 1985. Postharvest biology and technology: An overview. 192 p. In Postharvest technology of horticulture crops. University of California, Division of Agriculture and Natural Resources, Davis, California, USA.

Kader, A. 2002. Postharvest biology and technology: An overview. p. 39-47. In Kader, A.A. (ed.) Postharvest technology of horticultural crops. University of California, Agriculture and Natural Resources, Davis, California, USA.

Lelievre, J.M., A. Latche, B. Jones, M. Bouzayen, and J.C. Pech. 1997. Ethylene and fruit ripening. Physiology Plantarum 101:72739.

Lin, S., R.H. Sharpe, and J. Janick. 1999. Loquat: botany and horticulture. Horticultural Reviews 23:233-276.

Llácer, G., U.Aksoyand, and M. Mars. 1995. Underutilized fruit crops in the Mediterranean region. Cahiers Options Méditerranéennes 13:24-33.

Martínez-Calvo, J., M. Badenes, y G. Llácer. 2000. Descripciones de níspero japonés. España. 119 p. Generalitat Valenciana, Conselleria de Agricultura, Pesca y Alimentación, Dirección General de Innovación Agraria y Ganadería.

Martínez-Calvo, J., M.L. Badenes, G. Llácer, H. Bleiholder, H Hack, and U. Meier. 1999. Phenological growth stages of loquat tree (Eriobotrya japonica (Thunb.) Lindl.) Annals of Applied Biology 134:353-357.

Menéndez, A.O., L.S. Evangelista, O.M. Arenas, T.K. Bermúdez, M.A. del Villar, y A. Jiménez. 2006. Cambios en la actividad de a-amilasa, pectinmetilesterasa y poligalacturonasa durante la maduración del maracuyá amarillo (Passiflora edulis var. Flavicarpa degener). Interciencia 31(10):728-733.

Mitra, S.K., and E.A. Baldwin. 1997. Mango. p. 85-122. In Mitra, S.K. (ed.) Postharvest physiology and storage of tropical and subtropical fruits. CAB International, Wallingford, UK.

Pérez-Tello, G.O., J.C. Díaz-Pérez, I. Arispuro-Vargas, T.O. Briceño, y M.A. Martínez-Tellez. 1999. Actividad de polifenoloxidasa y peroxidasa en frutos de zapote mamey (Pouteria sapota). Revista Iberoamericana de Tecnología Postcosecha 1:120-125.

Rao, D.V.R., and B.S. Chundawat. 1989. Postharvest changes in respiration and enzyme activities in sapota (Manilkara achras (Mill.) Forsberg). Indian Journal of Plant Physiology 32(2):105109.

Razeto, B. 1988. El níspero. p. 58-72. In Sudzuki, F., y A. Gómez (eds.) Frutales no tradicionales. Universidad de Chile, Santiago, Chile.

Rouse, A.H., and C. Atkins. 1952. Heat inactivation of pectinesterase in citrus juices. Food Technology 6:291-294.

Speirs, J., C.J. Brady, D. Grierson, and E. Lee. 1984. Changes in the organization and messenger RNA abundance in ripening tomato fruit. Australian Journal of Plant Physiology 11:225-233.

Tobar, J.C. 2004. Efecto de la aplicación de Ethephon en precosecha, sobre la precocidad de madurez y la calidad comercial de frutos de níspero (Eriobotrya japonica Lindl.) cv. Golden Nugget, durante 
el almacenamiento refrigerado. 72 p. Tesis Ingeniero Agrónomo. Universidad Católica de Valparaíso, Facultad de Agronomía, Quillota, Chile.

Uchino, K., Y. Tatsuda, and K. Sakoda. 1994. Relation of harvest date and skin color to fruit quality of loquat "Mogi" during maturation. Journal of the Japanese Society for Horticulture Science 65:859865.

Undurraga, P., J.A. Olaeta, y X. Feito. 2006. Cosecha y postcosecha. p. 251-270. In M. Agustí, C. Reig, y P. Undurraga (eds.) El cultivo del níspero japonés. Pontificia Universidad Católica de Valparaíso y Universidad Politécnica de Valencia, Madrid, España.

Wang, P., B. Zhang, X. Li, Ch. Xu, X. Yin, L. Shan, et al. 2010. Ethylene signal transduction elements involved in chilling injury in non-climacteric loquat fruit. Journal of Experimental Botany 61:179-190.

Zanotti, C., S. García, and D. Moura. 2009. Cellulase and $\beta$-galactosidase activities in 'golden' and 'Gran golden' papaya softening. Revista Brasileira de Fruticultura 31:1178-1183.

Zhang, H.Z., S.A. Peng, L.H. Cai, and D.Q. Fang. 1990. The germplasm resources of the genus Eriobotrya with special references on the origin of Lindl. Acta Horticulturae Sinica 17:512.

Zheng, Y., Y. Xi, and T. Ying. 1993. Studies on postharvest respiration and ethylene production of loquat fruits. Acta Horticulturae Sinica 20:111-115. 